Article

\title{
Embodied Energy and Lifecycle Costs: Questioning (Mis)conceptions about Underground Construction
}

\author{
Michael Robert Doyle ${ }^{1, *}$, Philippe Thalmann ${ }^{2} \mathbb{D}$ and Aurèle Parriaux ${ }^{3}$ \\ 1 École d'architecture, Université Laval, Québec, QC G1R 3V6, Canada \\ 2 Laboratory of Environmental and Urban Economics (LEURE), École polytechnique fédérale de \\ Lausanne (EPFL), 1015 Lausanne, Switzerland \\ 3 École polytechnique fédérale de Lausanne (EPFL), 1015 Lausanne, Switzerland \\ * Correspondence: michael.doyle@arc.ulaval.ca; Tel.: +1-418-656-2131 (ext. 403103)
}

Received: 11 June 2019; Accepted: 8 August 2019; Published: 15 August 2019

\begin{abstract}
In the construction community, underground construction is perceived as being significantly more costly and more energy-consuming than comparable surface construction. Although the literature is scarce, studies that have attempted to quantify this difference tend to compare built projects in heterogeneous conditions. The objective of this article is to present the results of life cycle cost and energy consumption simulations conducted as part of the Deep City project at the École Polytechnique fédérale de Lausanne in Switzerland. This article begins by examining the preconceptions the construction industry seems to have about underground construction as reported in the press from 2007 to 2017. Then, we present the method and results of two unpublished studies on the differences in costs and energy consumption of a hypothetical commercial building project in two different geological contexts. We find that energy consumption can be $15 \%$ higher but also $4 \%$ lower. We also find that underground construction in unconsolidated sediment ground is approximately $23 \%$ more expensive, while only $10 \%$ in bedrock, which is significantly lower than the $200 \%$ to $300 \%$ differentials reported in previous studies. We attribute this to the level of detail of our studies, the inclusion of ground conditions, and conclude that our results help to dispel certain misconceptions about underground construction, which can contribute positively to urban sustainable development goals.
\end{abstract}

Keywords: underground construction; lifecycle analysis; construction cost; energy consumption; sustainability; construction industry; architecture; urbanism; engineering; geology

\section{Introduction}

Building underground is commonly perceived to be much more expensive and energy intensive than above ground. In this article, we challenge this preconception by first reviewing press articles from 2007 to 2017, finding that there is not a general consensus that would support such a claim. Given the lack of evidence provided in the press to back up the positive or negative portrayals of underground construction, as well as a lack in the scientific literature of similar studies, we proceed to present the results of cost and energy simulations, estimated over the lifecycle of a typical commercial building, realized either below or above ground. We demonstrate that differences are much smaller than commonly thought. Standard industry calculation tools do not systematically overestimate these differences, but they fail to account for geological conditions. We conclude that underground construction is not necessarily more energy consuming nor more costly. By taking into consideration the geological conditions of a construction site, underground construction can be a competitive alternative. Moving certain activities underground remains a promising strategy for reducing urban sprawl while preserving urban green spaces on the surface. 


\section{The 'Costs' of Underground Construction: Misconceptions?}

Switzerland, as a country sensitive to both the preservation of the traditional character of its urban and rural areas as well as the ease of movement between its otherwise disconnected alpine valleys, has a history of underground building and tunnel construction. The Gotthard Base Tunnel, completed in 2016 and significantly reducing the connection times for passenger and freight trains from the canton of Ticino on the southern side of the Alps to the rest of Switzerland, remains, as of 2019, one of the longest tunnels of its type in the world [1]. The topography of cities like Lausanne has encouraged multilevel construction into hillsides; high population densities have led to the decision to build additional transportation systems, shopping centers, and train stations underground. It is also increasingly common to find residential buildings in popular ski resort towns, such as Verbier, with two to three stories below ground, in order to meet the demand for increased living space while respecting laws related to building heights [2].

The increased attention by the private sector to the underground has led Switzerland to consider giving greater attention to underground resources in urban and land use planning. In 2005, funding was awarded to the Deep City project by the Swiss National Science Foundation to develop a state of the art of urban underground planning around the world and in Switzerland as well as to elaborate and test a method to evaluate an urban area's urban underground potential as a diagnostic tool for urban planning [3]. The project identified four resources warranting attention: Geomaterials, groundwater, (buildable) underground space, and geothermal energy. In parallel, the Federal Office for Spatial Development (ARE, Bundesamt für Raumentwicklung) prepared revisions to its Regional Planning Law (LAT, Loi sur l'aménagement du territoire), which, in its first phase, mandated limits to geographical expansion of existing urban areas. The ARE's second revision of the LAT, up for debate in Parliament in 2019, will declare the underground as a domain of responsibility for urban planning departments around Switzerland [4].

Considering the country's technical expertise with underground construction and the population's experience of the underground in many public places, it may be surprising that the 'third dimension' has not been picked up with greater enthusiasm by the planning and architecture communities in Switzerland. In 2010, Maire conducted a series of interviews with a real estate developer in Geneva, an architect and owner of a real estate agency in Lausanne and an employee of a Swiss federal real estate entity in order to identify the major barriers to underground construction perceived by experts in the field. Maire [5] observed that the reticence of these three experts towards underground construction was related to additional costs, which they perceived as significantly higher. This was not surprising in that it corresponded to scientific literature that also claimed that cost was the principle barrier to underground construction (and could reportedly be up to two-to-three-times more expensive) $[6,7]$. With the prevalence of discourse on sustainability and the increased attention given to the energy consumption of the construction industry, underground construction appears to be perceived without question as consuming significantly more energy. For instance, a report published by the Swiss Federal Office of Energy in 2017 for professionals recommended keeping any underground construction to a minimum in order to reduce the amount of embodied energy consumed [8]. The report however did not cite any sources nor outside data for verification.

In order to explain this reticence among the professional community, our initial hypothesis was that there must be particular projects or experiences that are the source of such general claims about underground construction and that these would appear in the written press, which mentioned the underground or underground resources in general. We collected 88 articles (see Appendix A) having appeared in the European or Swiss press in French or German for a ten-year period (2007-2017). The search used the databases of EuroPress, LexisNexis, and Swissdox and consulted directly the Swiss professional magazines Tracés, its German-language counterpart TEC21 and Hochparterre. Seventy-one of the articles had been published in local or national Swiss newspapers or the professional journals of the architecture and engineering community. The remaining articles either appeared in French or 
Belgian newspapers or professional reviews (e.g., Le Moniteur). The objective was not to get an exhaustive overview, but rather to take the general pulse of attitudes towards the underground in the press.

The articles tended to be reporting on building projects (45/88), parking (16/88), or infrastructure projects (6/88), but included articles featuring a wider discussion on the underground (21/88), often related to its role in reaching objectives for urban sustainability. Between 2007 and 2017, three building projects received the most attention in the press: The renovation of the Geneva main train station, which proposed a solely underground alternative for the expansion (16/88); the controversial Art and Ethnography Museum (Musée d'art et d'ethnographie) by Jean Nouvel whose surface presence raised questions about whether the project should instead be underground; and the Ethnography Museum (Musée d'ethnographie), whose expansion was planned to be underground and the object of an international competition. All these projects are situated in Geneva and so would have received additional press in the evening news throughout most of Switzerland if not principally in the French-speaking cantons. Our interest in single building projects meant excluding rail projects that were not main stations (like the Geneva station), including tunnels. We did not pick up articles debating the Geneva-area CEVA project, which was thoroughly documented elsewhere [5]. Articles consulted tended to report on the latest obstacles, major decisions or local backlash to the projects, but portrayed a positive response overall to the underground, whether in helping to save nearby neighborhoods from having to expropriate a large number of its residents (Geneva Cornavin station), in preserving the character of an existing building (Art and Ethnography Museum), or in the positive ambiance delivered by the winning architects (Museum of Ethnography).

The articles reviewed do not give the overall impression that any particular project since 2007 has become a reference for a negative experience with the underground. Most of the articles either portrayed underground construction positively (28/88) or were neutral (43/88). The negative articles $(17 / 88)$ as well as several of the more neutral articles, weighing positives and negatives in underground construction, tended to mention the potential increases in cost, increases in energy consumption (embodied energy particularly) as well as the potential uncertainty of ground conditions. Throughout many of the articles, energy consumption and project costs tend to be seen either positively (where they are thought to potentially decrease with underground construction) or negatively (where they are perceived as likely to rise). This uncertainty is itself considered a disadvantage of underground construction-a general increase in the number of inputs, actors, project length, and overall complexity of the construction project. These claims, as they are reported in the media however, lack sources or evidence that could be examined in order to attempt any verification of why, in a particular instance, one project realized significant savings (either in energy or construction costs) and another experienced delays and budget overruns. The attempt to settle once and for all on either increased savings or increased costs risks does not seem feasible nor desirable, and instead risks reducing the relationship between underground construction and 'cost' to a causal link that can be communicated as a 'rule of thumb', published in reports or integrated into sustainability evaluation tools.

The findings from the Deep City project suggest that it would be unwise to decide so categorically on the advantages or disadvantages of an underground project on these terms, and that we can in fact anticipate whether a partially or fully underground project can expect increases or decreases in costs and energy consumption. This article will communicate the results of two parallel studies on surface and subsurface variations of a hypothetical commercial project in Switzerland. The first study, conducted as part of a Master of Environmental Engineering diploma project, evaluated the energy consumption during the lifecycle of a building [9]. The second, realized as part of a doctoral dissertation in Environmental Engineering, performed a similar lifecycle analysis on the hypothetical costs of such a building [5]. The article will proceed as follows: First, it will present the overall simulation methodology adopted and the particularities of simulation for each study. Then it will report on the results of the energy evaluation, comparing its results to those provided by two evaluation methods available to professionals in Switzerland: The SméO tool and the method proposed by the SIA 2040 standard. Then, the results of the economic analysis will be presented, followed by a general discussion 
looking at how evaluation methods can help to manage (if not entirely eliminate) uncertainty and what generalizations, if any, can be gleaned reasonably for planning or policy-making.

\section{Methodology: Simulating Energy Consumption and Costs in the Lifecycle of a Building}

Previous studies of energy consumption and construction costs of underground construction tend to be empirically and statistically oriented. The concern for energy conservation in the 1970s inspired an increased interest for underground and earth-berm construction in order to take advantage of the relative thermal stability of the ground [10-12]. The research is inductive, deriving best practices from evidence of existing buildings. The energy savings are unfortunately loosely quantified and difficult to generalize or adapt to other contexts. A recent review is exceptional in that it combines the morphological strategies for passively heating and cooling partially- or fully-subsurface buildings with the equations adopted for simulating their thermal behavior [13]. However, it does not have any empirical data on the cases it cites, nor does it attempt to apply the formula to simulate potential energy savings.

A similar tendency can be observed in the research into projects costs of underground construction. Maire [5] observes in his dissertation that the two most cited comparative studies of surface and subsurface projects draw largely divergent conclusions and tend to compare building types or projects in ways that make it difficult to isolate the impact of the underground. A more recent review quantifies construction costs per country or region as averages per square meter [14], but this is too general to be useful input for a specific construction project. Furthermore, to limit the evaluation to the cost of construction fails to account for potential savings in operational and maintenance costs, where underground construction would hypothetically be advantageous.

For these reasons, we chose to adopt a model-based method of simulation. Building simulation allows us to isolate a particular hypothetical scenario and to employ mathematical models generalized from inductive research (into energetic or economic phenomena) in setting up the causal or probabilistic mechanisms operating between the model's component parts $[15,16]$. The interactions between the component parts are evaluated over the life of the building, in accordance with the ISO 14040 Lifecycle Analysis [17]. Surface and subsurface variations of a commercial center were designed with the same common features: Five floors with the same proportion of services, emergency stairs and storage, four-meter floor-to-floor distances, an atrium space providing natural light into three of the five retail floors. The steel structure, poured concrete foundation, windows, and exterior cladding were all specified according to the Swiss sustainability Minergie standard [18]. In order to avoid major differences in cost and energy performance due to design decisions of the façade, the surface variant was conceived with glazing only on the atrium and at the ground level (as storefronts) —otherwise, the façade lacks glazing. The simulations compared the surface variant to two alternatives of the subsurface variant: One in 'good quality' ground (bedrock) and 'poor quality' ground (unconsolidated sediments), which are two ground types encountered frequently in Lausanne. These differences specifically impact the type of foundations needed as well as the volume of unconsolidated sediment or rock to be excavated. Sections of these three variants are depicted in Figure 1 with the impact of ground conditions summarized in Table 1. Architect and professor of architecture at the EPFL, Pierre Von Meiss, designed the building and Claude Risch of Emch + Berger calculated the dimensions for the building structure [9]. 

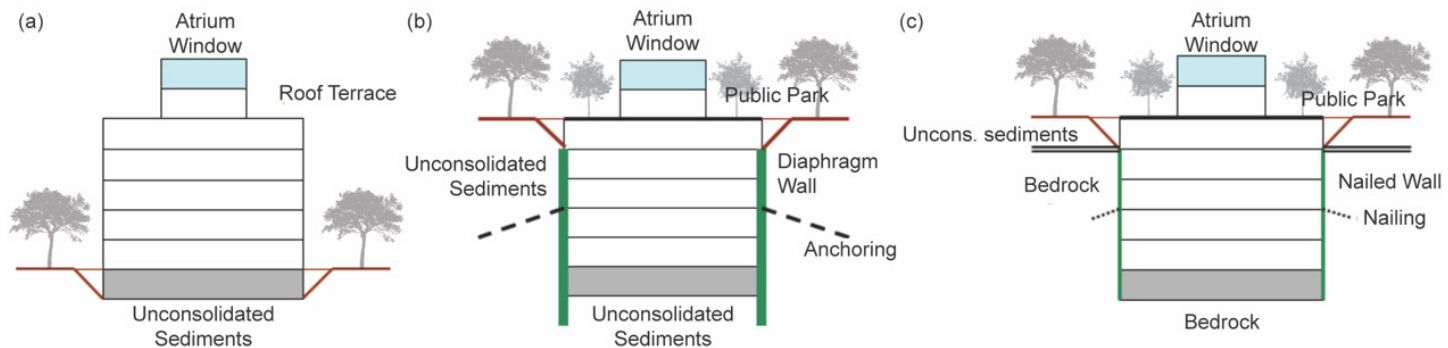

Figure 1. Three variants: Surface option (a), underground option in less favorable conditions (unconsolidated sediments) (b), underground option in more favorable conditions (bedrock) (c), adapted from Poux 2008, p. 11.

Table 1. Technical details of the three commercial variants (adapted from Maire 2011, p. 115)

\begin{tabular}{|c|c|c|c|}
\hline Construction Elements & Variant 1 (Surface) & $\begin{array}{c}\text { Variant } 2 \text { (Underground } \\
\text { Unfavorable) }\end{array}$ & $\begin{array}{c}\text { Variant } 3 \text { (Underground } \\
\text { Favorable) }\end{array}$ \\
\hline Excavation & $\begin{array}{c}8000 \mathrm{~m}^{3} \\
\text { (unconsolidated) }\end{array}$ & $\begin{array}{c}40,000 \mathrm{~m}^{3}\left(3700 \mathrm{~m}^{3} \text { of }\right. \\
\text { material mixed with } \\
\text { bentonite })\end{array}$ & $\begin{array}{l}38,000 \mathrm{~m}^{3}\left(8000 \mathrm{~m}^{3} \text { of }\right. \\
\text { unconsolidated sediment } \\
\left.\text { and } 30,000 \mathrm{~m}^{3} \text { of rock }\right)\end{array}$ \\
\hline Foundations & 20 footings & 20 light footings & 20 light footings \\
\hline Structure & Columns, slab & $\begin{array}{c}\text { Diaphragm wall }(80 \mathrm{~cm} \\
\text { total thickness) }\end{array}$ & $\begin{array}{l}\text { Berlin wall ( } 25 \mathrm{~cm} \text { total } \\
\text { thickness) }\end{array}$ \\
\hline Thickness Roof Terrace & $30 \mathrm{~cm}$ & $\begin{array}{c}45 \mathrm{~cm} \text { (for passage of } \\
\text { vehicles) }\end{array}$ & $\begin{array}{c}45 \mathrm{~cm} \text { (for passage of } \\
\text { vehicles) }\end{array}$ \\
\hline
\end{tabular}

\subsection{Simulating Energy Consumption}

According to the ISO 14040, Lifecycle analyses (LCA) evaluate the consumption of energy, raw materials, waste and any services affecting the building from the site preparation phase to its demolition or dismantling. In her simulations conducted for the Deep City project, Poux [9] accounted for the construction, operation, and demolition phases of the three alternatives. The construction phase included the production of construction materials, their transport to the fictional building site and the energy consumption of necessary site equipment. The operation phase estimated the energy expenditures of the heating, ventilation and air-conditioning systems, hot water, as well as the materials replaced during renovation phases (excluding variations based on the behavior of individuals in the building as well as regular maintenance like painting and cleaning). The demolition phase accounted for the energy consumption of demolition equipment and waste management calculated according to the 2008 performance of the Lausanne incineration center and with the hypothesis that all materials are sorted on site, instead of being shipped elsewhere.

The energy consumption during the fabrication, transport (during fabrication), renovation and demolition of the building components was based on the estimations provided by the Swiss government in 2007 [19]. Three indicators were adopted for energy consumption: Raw energy (related to fossil, nuclear or hydraulic energy quantifies in megajoules (MJ)), global warming potential (GWP, proposed by the Intergovernmental Panel on Climate Change for quantifying the contribution of an emitted gas to global warming), and ecopoints (a Swiss industry standard, which will be given less emphasis in this article as it is less comparable with foreign examples). The building components include the load-bearing structure, the insulation, windows and frames (both originally installed and replaced), but do not account for interior furnishings. The energy consumed by the transport of the materials to the site (for both construction and renovation) was calculated for a 38-ton truck travelling $10 \mathrm{~km}$ after [20]. The energy cost of excavation and removal of rock or soil from the site adopted the same estimations with the additional energy consumption of a hydraulic shovel and its fuel and oil consumption. 
The operating phase of the building evaluates the energy consumption of the building accounting for heat loss through the envelope, foundation or ventilation system, the heat generated by people and indoor equipment (e.g., lighting) and the variations of the heating and cooling systems due to seasonal changes in outdoor temperature. These simulations were performed with the Lesosai software (developed at the time by the Leso-PB laboratory at the EPFL and by the company E4Tech since 2009) on a monthly and hourly basis according to Swiss and European norms. The monthly thermal assessment was calculated according to the SIA 380/1 norm of the Association of Swiss Architects and Engineers. The hourly assessments adopted the European EN 13790 and EN 15603 norms. The Finite Element subsurface FLOW and transportation simulation system (Feflow) software was used to provide more detailed estimates of the thermal conductivity of the ground [21]. Poux [9] found that the Lesosai software tends to assume a linear decrease in temperature from the surface, underestimating the thermal stability provided by the ground deeper than the heterothermic level (about the first four meters) over the course of the year. In the analysis of the results, the estimates of the Feflow model were used to replace those of the Lesosai model, using the estimates for the heterothermic zone as a common denominator. The simulations accounted for a building life of 60 years and will be presented in the results in Section 4.1.

\subsection{Simulating Project Lifecycle Costs}

For each variant, Maire [5] examined the costs of construction, operating and purchasing the land for the building. The estimation of construction costs was conducted by the Institut pour l'Économie de la Construction, based in Lausanne, Switzerland, using the CFE (Code des frais par éléments) method, which calculates the prices of all the building components from the macro (walls, ceilings, etc.) to the micro (interior doors, windows, etc.) scale. This is comparable to a standard RICS (Royal Institution of Chartered Surveyors) order of cost estimation method. Prices are drawn from data available from the Federal Office of Statistics (OFS), produced by analyzing the costs for the elements of previous projects gathered by experts. The SIA 416 standard was followed again in establishing the floor surface area and built volume. The quantities of each building component were estimated according to the CFE SN 506502 standard, published by the Centre Suisse d'étude pour la rationsliation de la construction [Swiss Centre for the Rationalization of Construction]. The estimated lengths of time for each construction site calculated by Emch \& Berger for Poux's simulations were used to calculate the labor costs. Additional costs included a budget for unforeseen costs of $10 \%$ of the total construction costs (taxes included). Certain conditions were not taken into consideration, including the site hydrology and the maintenance costs (e.g., of the building façades).

The operating costs were calculated according to the building characteristics established in Poux's energy simulations. First, the annual cost of energy consumed for each variant was estimated using the statistics of the Swiss Federal Energy Office (OFEN) for the year 2007, in which the cost of electricity was on average 16.4 centimes per kilowatt-hour and the cost of natural gas, 9.1 centimes per kilowatt-hour. Energy consumed is what is billed to the consumer, meaning that the energy consumed producing the electricity or the natural gas is not considered here. The results section will discuss the implications for the financial impact of energy consumption, which differ slightly from those presented for the simulations. Second, the costs were discounted over 50 years at a rate of $5 \%$ with an increase of $2 \%$ in energy costs each year. The lifespan of each building was considered to be 50 years.

For the land acquisition costs, Maire's analysis took the values in price per square meter for a hypothetical empty plot of $1500 \mathrm{~m}^{2}$ in Geneva, Switzerland, where a commercial project was legally permitted. For comparison, the study looked at three different price brackets, using values published by the real-estate consultancy Wüest Partner (Immo-Monitoring 2008): 2620 Swiss Francs (CHF) per square meter, $4020 \mathrm{CHF} / \mathrm{m}^{2}$ and $10,310 \mathrm{CHF} / \mathrm{m}^{2}\left(\mathrm{USD}_{2007} 2180,3350\right.$ and 8590 respectively). For a plot of $1500 \mathrm{~m}^{2}$, this translates to 3.93 million CHF for the least expensive scenario, 6.03 million CHF for a scenario of medium cost and 15.47 million CHF for the most expensive ( $\mathrm{USD}_{2007} 3.28,5.03$, and 12.89 million respectively). The results Section 4.2 will compare the impact of different aspects of the 
three variants on the total costs, in particular the differences resulting from the project being surface or subsurface.

\section{Results}

\subsection{Energy Simulation Results and Comparison with the Tools Available to the Industry}

The results of the energy simulations reveal that the subsurface variant in less favorable ground conditions (unconsolidated sediments) would consume a greater amount of energy due to the additional concrete necessary for its foundations (diaphragm wall). Interestingly, the subsurface variant in favorable ground conditions (bedrock) would consume a slightly lower amount of energy than the surface variant (Table 2). Breaking the energy consumption into the three phases (Figure 2) reveals that the higher energy expenditures of the subsurface variants incurred during the construction (related to excavation) phases are compensated over the lifecycle of the buildings by a lower energy use during operation (due in particular to the thermal stability of the ground). The simulations also suggest that the subsurface variant in favorable ground conditions would have a lower global warming potential than the surface variant, due not only to lower energy consumption related to stable ground conditions, but especially to the lack of energy consumed by the fabrication, delivery, and replacement of façade materials.

Table 2. Savings incurred during the construction phase (in $\mathrm{MJ} / \mathrm{m}^{2} / \mathrm{yr}$ ).

\begin{tabular}{cccc}
\hline Phase & Variant 1 (Surface) & $\begin{array}{c}\text { Variant 2 (Underground } \\
\text { Unfavorable) }\end{array}$ & $\begin{array}{c}\text { Variant 3 (Underground } \\
\text { Favorable) }\end{array}$ \\
\hline Construction & 66 & 100 & 69 \\
Operation & 799 & 761 & 764 \\
Disassembly & 6 & 10 & 6 \\
Total & 872 & 872 & 840 \\
\hline
\end{tabular}

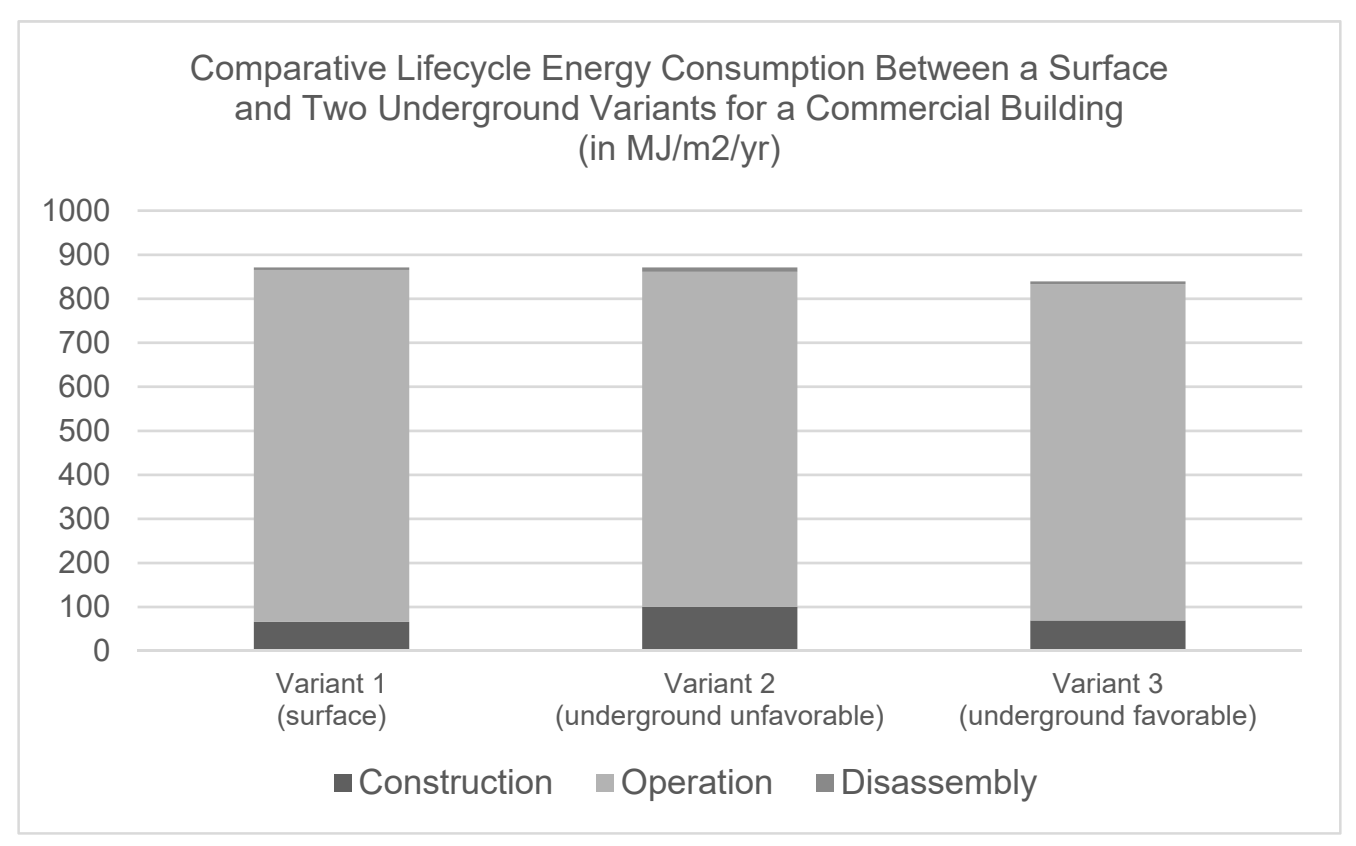

Figure 2. Estimated construction costs incurred by excavating in the less favorable (unconsolidated sediments) is compensated in comparison with the surface option by lower operating costs (adapted from Poux 2008, p. 63).

It is likely that few architecture or engineering firms (or their clients) evaluate projects to this level of detail. In Switzerland, there are two sustainability calculators currently available on the market that 
can be used at various stages of a building project to estimate its energy efficiency: The Swiss Society of Engineers and Architects (SIA) has published the SIA 2040 standard for calculating the energy consumption of a building project and sells licenses for its Microsoft Excel-based calculator; the SMEO tool (2017 version, http://smeo.ch), the output of a federal cantonal and municipal collaboration initiated by the city of Lausanne, provides a lifecycle analysis based on the SIA 112 and SIA 2040 standards. The values of the three variants were entered into each sustainability calculator to determine whether these publicly available forms of 'simulation' were finding major differences between the surface and subsurface options.

The interest was not in which most 'accurately' represented the values of our simulations, but rather what the degree of difference was between the three variants. The hypothetical scenario was one in which a project in the design development phase can test the performance of project variations. First, and significantly, neither the SIA nor the SMEO tools allow for specifying the type of foundation. This is evident also from a standard upon which the SIA 2040 and SMEO tools draw from in their calculations: The SIA 2032 standard (specifically its Appendix D). This means that comparison between different geological conditions and their impact on the foundation type is not possible. In terms of data entry, the differences between the surface and underground variants in the SIA 2040 tool lie in the volume of building that is placed underground $\left(6000 \mathrm{~m}^{3}\right.$ for the surface; $36,000 \mathrm{~m}^{3}$ for the subsurface) and consequently the surface area of façade that is aboveground (3200 for the surface; zero for the subsurface). For the SMEO tool, the only difference is the volume of the portion of the building underground.

The results of the evaluations with the two sustainability calculators provided very different proportional differences from those of Poux (Table 3). The SIA 2040 calculation estimates only a 1\% higher energy consumption for the underground variants and a $5 \%$ higher production of greenhouse gases. The SMEO tool estimates a 10\% higher energy consumption and a $17 \%$ higher production of greenhouse gases. Comparatively, Poux's simulations estimated a similar if not identical consumption of energy between the surface option and the subsurface variant in less favorable ground conditions and a $4 \%$ decrease in energy consumption for the variant in favorable ground conditions. Greenhouse gas production was estimated as $15 \%$ higher in less favorable ground conditions and, again, $4 \%$ lower in the subsurface variant in favorable conditions.

Table 3. SMEO and SIA 2040 ready-available simulation tools for the Swiss market do not account for the differences in geological conditions. Nevertheless, the cost comparisons do not reveal any major upcharge in lifecycle costs between surface and subsurface options.

\begin{tabular}{|c|c|c|c|c|}
\hline Simulation Tool & Indicators & $\begin{array}{l}\text { V2/V1 (Option in } \\
\text { Unconsolidated } \\
\text { Sediments versus } \\
\text { Surface Option) }\end{array}$ & $\begin{array}{l}\text { V3/V1 (Option in } \\
\text { Bedrock versus } \\
\text { Surface Option) * }\end{array}$ & $\begin{array}{c}\text { V2/V3 (Option in } \\
\text { Unconsolidated } \\
\text { Sediments versus } \\
\text { Bedrock)* }\end{array}$ \\
\hline \multirow{2}{*}{ SMEO } & Primary Energy & 1.10 & 1.10 & - \\
\hline & $\begin{array}{l}\text { Global Warming } \\
\text { Potential }\end{array}$ & 1.17 & 1.17 & - \\
\hline \multirow[b]{2}{*}{ SIA 2040} & Primary Energy & 1.01 & 1.01 & - \\
\hline & $\begin{array}{l}\text { Global Warming } \\
\text { Potential }\end{array}$ & 1.05 & 1.05 & - \\
\hline \multirow{2}{*}{$\begin{array}{c}\text { Our project (Poux } \\
2008)\end{array}$} & Primary Energy & 1.00 & 0.96 & 1.03 \\
\hline & $\begin{array}{c}\text { Global Warming } \\
\text { Potential }\end{array}$ & 1.15 & 0.96 & 1.23 \\
\hline
\end{tabular}

* the SMEO and SIA 2040 tools do not account for differences in foundation due to differences in ground conditions.

It is not the objective of this study to speculate as to the source of these differences (except of course for human error, although there are actually few user entries to be made in the calculators), but rather to note the subtlety of these differences. An increase in energy consumption of $10 \%$ may 
not be significant for other decisions being made about the design or feasibility of the project. It is nevertheless unfortunate that neither tool accounts for the ground conditions-and therefore the type of foundations needed and the insulating factor of the ground. It is not possible to appreciate that, on certain sites, the underground option would in fact save energy. These savings might, of course, be incurred only over the lifetime of the building and therefore it is important to consider, as we will do in the next section, the differences in lifecycle cost of the three variants.

\subsection{Cost Simulation Results}

Maire's [5] calculations find, unsurprisingly, that the construction costs of the subsurface variants are higher than the surface only option. However, this difference is significantly lower than the magnitudes of two to three reported in the literature Maire reviewed-in less favorable ground, the cost of the subsurface variant is $23 \%$ higher than the surface variant and only $10 \%$ higher in favorable ground. Separated into the macro-elements of the CFE method, it is clear that the increase in costs is related to mostly preparatory work, the installations necessary for the construction site and the professional fees related to longer construction sites (Table 4). In the case of the preparatory work, for instance, the less favorable ground conditions mean that the excavation and preparation of the site for the foundations is more than ten times (10.28) the cost as it would be on the surface; in favorable ground, it is four (4.08) times. However, in the total project costs, the preparatory work accounts for only $14 \%$ in less favorable ground conditions and $6 \%$ in favorable conditions. This increase is therefore absorbed in the overall construction costs.

Table 4. Relative cost comparison between estimated construction costs of the three variants.

\begin{tabular}{cccc}
\hline Construction Work & $\begin{array}{c}\text { V2/V1 (Option in } \\
\text { Unconsolidated } \\
\text { Sediments versus } \\
\text { Surface Option) }\end{array}$ & $\begin{array}{c}\text { V3/V1 (Option in } \\
\text { Bedrock versus } \\
\text { Surface Option) }\end{array}$ & $\begin{array}{c}\text { V2/V3 (Option in } \\
\text { Unconsolidated } \\
\text { Sediments versus } \\
\text { Bedrock) * }\end{array}$ \\
\hline Preparatory work & 10.28 & 4.08 & 2.52 \\
Foundations & 2.78 & 2.78 & 1.00 \\
Exterior walls & 0.73 & 0.73 & 1.00 \\
Roof & 1.00 & 1.00 & 1.00 \\
Interior structure & 0.86 & 0.86 & 1.00 \\
Installations & 0.96 & 0.96 & 1.00 \\
Interior design & 1.00 & 1.00 & 1.00 \\
Installations & 1.25 & 1.09 & 1.15 \\
Secondary costs & 1.03 & 1.03 & 1.00 \\
Professional fees & 6.40 & 4.00 & 1.60 \\
Other fees & 1.19 & 1.09 & 1.10 \\
Suspense account & 1.23 & 1.10 & $\mathbf{1 . 1 2}$ \\
\hline Total & $\mathbf{1 . 2 3}$ & $\mathbf{1 . 1 0}$ & \\
\hline
\end{tabular}

* the SMEO and SIA 2040 tools do not account for differences in foundation due to differences in ground conditions.

The operating costs of the building were calculated by Maire as the billed energy consumed, which meant—including from Poux's [9] simulations—only the consumption in electricity of the cooling system, lighting, ventilation, and appliances and in natural gas of the heating needs and the warm water for the sanitary systems. The underground variants, because of the thermal properties of the ground, both consume less energy than the surface building, providing a savings in favorable ground conditions of $5 \%$ and a savings of $4 \%$ on the yearly energy costs in unfavorable ground (Table 5). The $1 \%$ difference between the two underground variants is due to the diaphragm wall necessary to stabilize the foundations in the unconsolidated sediments providing a greater thermal insulation than the soil nailed wall designed for the bedrock. When adding the operation costs to the construction costs, the cost of the underground variant in less favorable ground is $21 \%$ higher than the surface 
option and $8 \%$ more expensive in favorable ground, which demonstrates the important influence of the geological conditions of the ground on the difference in cost of underground construction.

Table 5. Comparison between the three variants of operating costs (adapted from Maire 2011, p. 125).

\begin{tabular}{|c|c|c|c|}
\hline \multirow[b]{2}{*}{ Energy Type } & \multicolumn{3}{|c|}{ Proportion of Total Costs/Year } \\
\hline & $\begin{array}{l}\text { V2/V1 (Comparison } \\
\text { Less Favorable) }\end{array}$ & $\begin{array}{l}\text { V3/V1 (Comparison } \\
\text { More Favorable) }\end{array}$ & $\begin{array}{c}\text { V2/V3 (Comparison Less } \\
\text { Favorable to More Favorable) }\end{array}$ \\
\hline Electricity & 1.00 & 0.99 & 1.00 \\
\hline Gas & 0.69 & 0.75 & 0.92 \\
\hline Total & 0.95 & 0.96 & 0.99 \\
\hline
\end{tabular}

The decision to finance a construction project is of course influenced by the cost and availability of developable land. Maire included the potential cost of land, for a low, medium, and high cost hypothetical plot of land in Geneva, Switzerland. When looking at the impact of an increase in price per square meter, it is evident that as the price of land acquisition increases, the relative importance of the project's being above or below ground decreases. For instance, the difference in cost of the underground variant in less favorable ground conditions decreases to $15 \%$ from $23 \%$ when opting for a highly valued location (like some of the more desirable commercial streets in Geneva) (Table 6). If the ground conditions are more favorable, the cost difference is decreased from $10 \%$ to $6 \%$.

Table 6. Comparison when adding the cost of land purchase (adapted from Maire 2011, p. 126).

\begin{tabular}{cccc}
\hline $\begin{array}{c}\text { Building/Land } \\
\text { Combinations }\end{array}$ & $\begin{array}{c}\text { V2/V1 (Option in } \\
\text { Unconsolidated } \\
\text { Sediments versus } \\
\text { Surface Option) }\end{array}$ & $\begin{array}{c}\text { V3/V1 (Option in } \\
\text { Bedrock versus } \\
\text { Surface Option) }\end{array}$ & $\begin{array}{c}\text { V2/V3 (Option in } \\
\text { Unconsolidated } \\
\text { Sediments versus } \\
\text { Bedrock) * }\end{array}$ \\
\hline $\begin{array}{c}\text { Only Building } \\
\text { Building and lowest land } \\
\text { cost }\end{array}$ & 1.23 & 1.10 & 1.12 \\
\hline $\begin{array}{c}\text { Building and median } \\
\text { land cost }\end{array}$ & 1.19 & 1.09 & 1.11 \\
\hline $\begin{array}{c}\text { Building and highest } \\
\text { land cost }\end{array}$ & 1.15 & 1.08 & 1.08 \\
\hline the SMEO and SIA 2040 tools do not account for differences in foundation due to differences in ground conditions
\end{tabular}

\section{Discussion and Recommendations}

The results of the energy and cost simulations challenge some of the more negative assumptions about underground construction appearing in the press. These assumptions with regards to energy consumption also appear in recommendations made by SwissEnergy for the construction industry with regards to the Switzerland's sustainability objectives (under the banner of a '2000-Watt Society'). However, these recommendations are not backed up by independent sources nor do they provide any tools for evaluating the energy consumption of a building. The Swiss Society of Engineers and Architects (SIA), which publishes the standards for the construction industry, does not mention the underground in its SIA 2040 norm. As our study here finds, the calculators that are available for actors of the construction industry (and based on the SIA norms) unfortunately do not take into account different geological conditions, which can make a difference in construction costs and energy use.

It does not appear, however, that these tools are unfairly biased against underground construction. Our simulations with both the SIA 2040 calculator and SMEO found that the underground options for a hypothetical commercial project consumed only $1 \%$ to $17 \%$ more energy than the surface option. If these tools accounted for the geological conditions of the ground (or at least different types of foundation 
walls), then the potential savings Poux observed in her more thorough calculations could be observed by other actors of the construction industry and integrated into the project development phase.

Our examination of the press, as well as our comparative simulations, lead us to conclude that much of the assumptions on the higher cost and higher energy consumption of underground construction are unfounded and uncritically perpetuated. In the articles we reviewed, only one mentioned social acceptability as a potential obstacle [22]. Where the ambiance of underground spaces is appreciated by visitors, general acceptability seems relatively high. Such acceptance depends on the project however and is difficult to generalize to all underground spaces. As we mentioned in the introduction, Switzerland is a country whose population is accustomed to partially-underground commercial, cultural, and transport projects. Other countries or cities may not have the same tradition nor cultural experience.

Underground construction was often reported in the press to be a positive contributor to sustainable urban objectives, despite the negative aspects mentioned previously. Articles that discussed the objectives of the 2000-Watt society objectives were noticeably critical of underground development. Whether the statements were made by developers or local officials [23], building underground was considered excessive in terms of energy consumption and an 'ecological bottomless pit' (une gouffre écologique). This negative attitude towards the underground echoes the previously cited recommendations made by Swiss Energy to build underground as little as possible. However, this attitude is not reflected everywhere: If recent changes to a mixed neighborhood in Neuchâtel succeeds in reducing the presence of cars by putting them underground and concentrated in a single location [24], another in Lausanne seeks to reduce its negative ecological impact by avoiding underground construction at all costs [25].

The specific constraints and evolution of a building project will ultimately condition the feasibility of underground construction. However, such conditions are never mentioned in the press to support the statements made about the higher cost or energy consumption of the underground. Without evidence, such statements risk becoming common belief. It is not solely the role of the press to dispel myths such as these, but rather requires a concerted effort between the developers of the sustainability evaluation tools, the recommendations of national sustainability programs or national institutions (which tend to perpetuate these myths) as well as the scientific community whose hypotheses or experimental setups (such as energy consumption or cost simulations) may themselves unconsciously incorporate a prejudicial form of common sense about the underground.

This article alone cannot claim to provide all the evidence necessary to argue that underground construction is not de facto more expensive nor more energy-consuming. First of all, it focused on the Swiss context, which has a long tradition of underground construction. Nevertheless, the misconceptions about underground construction are observable in the press and the empirical work presented here showed that a national and historical expertise is not always manifested in the local and present time. As sustainability has become a worldwide concern, the misconceptions about the role of the underground supporting sustainability goals should be examined in other countries. Second, the empirical work presented in this article is based on simulations of specific variations of a commercial project. The simulation method permitted the evaluations of cost and energy consumption to be as precise as possible, while relying on the European standard method of lifecycle analysis. The method was beneficial for comparing with 'simulation' tools available to local industry (the Sméo and SIA 2024 tools), but could be carried out in other contexts as well. The attention given to a commercial project has its limits, as does comparing surface and subsurface options: Other potential building types are excluded, and combined surface/subsurface options are not evaluated. Future work could examine other building types, comparing lifecycle analysis with other local sustainability calculators.

\section{Conclusions}

Underground construction in urban areas suffers from numerous negative preconceptions, as much with regard to cost as to overall environmental performance, particularly in terms of energy consumption. The study presented here demonstrates that these preconceptions are misconceptions. 
First, the geological studies that are required for any construction project can significantly reduce the a priori uncertainty related to the underground, revealing eventual problematic ground conditions or the presence of pollutants. The absence or inadequacy of such preliminary studies would amount to a professional error by the engineer. Second, the possible increase in construction costs varies in the case examined here between 10 and 25 percent, depending on the geological conditions, and this without taking into account additional savings provided by geothermal systems or conjoint surface-underground construction. Finally, the energy performance over the life of the building is similar to that of a well-insulated equivalent on the surface, including in terms of embodied energy necessary for excavation, transport of excavated material to a landfill and of the production of the construction materials. It is unfortunate that such misconceptions inform urban planning, design, and architecture, particularly considering the possibility underground construction offers for increasing built density while respecting local height limits, preserving urban green spaces and public open spaces, as well as supporting urban biodiversity. Of course, the study here only investigated variations on a commercial building type and future research could conduct simulations with different building types or geological conditions. However, our hypothesis is that such investigations are more likely to refine the differential between surface and subsurface construction than they are to significantly modify the orders of magnitude between them. The study presented here is thereby an initial effort to dispel certain misconceptions about underground construction as well as a reminder that prejudices that become rules of thumb benefit from being regularly and critically assessed.

Author Contributions: Conceptualization, methodology, validation, formal analysis, investigation: M.R.D., P.T. and A.P.; Writing—original draft preparation: M.R.D.; Writing—review and editing: P.T. and A.P.; Supervision, project administration and funding acquisition: P.T. and A.P.

Funding: The results reported from Maire (2011) received funding from the Swiss National Science Foundation as part of PNR 54.

Acknowledgments: The review of press articles was assisted by the work of Cilette Bouche and Christophe Pittet, students in the Master of Architecture program at the EPFL, supervised by M. Doyle.

Conflicts of Interest: The authors declare no conflict of interest.

\section{Appendix A. Press Articles Reviewed}

The following appendix presents the articles reviewed for their discussion and portrayal of underground construction in the French, English, and German-language press, since 2007. The focus was on Switzerland and Swiss projects, which would have been more likely to have been picked up by the professional and political community in Switzerland. The analysis was interested in whether the article was reporting on negative aspects of the underground or a negative experience, for instance related specifically to cost, or if they were specifically arguing against underground construction, in a more editorial fashion. If the article examined the positives and negatives of underground construction in general or in the context of a specific project, then it was considered to be neutral. A positive portrayal of the underground is essentially the opposite of the negative portrayal, in which underground construction in general or the underground option of a project is being argued for.

Table A1. Title, data, source and overall portrayal of the press articles reviewed, presented in chronological order

\begin{tabular}{cccc}
\hline Article Title & Date & Source & Portrayal \\
\hline Un quartier mixte revalorise Neuchâtel & $07-04-10$ & La Liberté & Positive \\
\hline $\begin{array}{c}\text { Les commerçants ne veulent pas du futur } \\
\text { parking souterrain de la place du Marché }\end{array}$ & $07-07-07$ & 24heures & Negative \\
\hline Un toit doré pour l'ethnographie à Genève & $08-05-06$ & Le Temps & Positive \\
\hline $\begin{array}{c}\text { La cinémathèque pourra sauver ses trésors dans } \\
\text { de nouveaux locaux }\end{array}$ & $08-12-18$ & 24heures & Positive \\
\hline
\end{tabular}


Table A1. Cont.

\begin{tabular}{|c|c|c|c|}
\hline Article Title & Date & Source & Portrayal \\
\hline L'homme qui revait la démesure pour Vevey & 09-01-19 & Le Temps & Neutral \\
\hline Réaménagement sur la place du Marché & $09-02-11$ & $S D A$ & Neutral \\
\hline Tout un monde-sous nos pieds & $11-09-03$ & 24heures & Neutral \\
\hline $\begin{array}{l}\text { Sous-sol censuré. Patrimoine suisse Genève ne } \\
\text { peut pas parler du Musée d'art et d'histoire aux } \\
\text { Journées européennes du patrimoine }\end{array}$ & 11-09-09 & Le Temps & Negative \\
\hline $\begin{array}{c}\text { "Pour se densifier, les villes vont aussi se } \\
\text { développer en sous-sol" }\end{array}$ & $11-10-26$ & Le progrès & Positive \\
\hline Le sous-sol, horizon neuf des villes DOUBLON & $11-11-07$ & Le Temps & Positive \\
\hline Jean Nouvel, puissant et contesté & $11-11-21$ & Le Temps & Neutral \\
\hline $\begin{array}{c}\text { Pour sauver } 23 \text { mètres de "son" quartier, Rémy } \\
\text { Pagani est prêt à toutes les folies-Fagioli }\end{array}$ & $11-12-18$ & Le Matin & Negative \\
\hline Unheil in der Unterwelt & 12-03-01 & Hochparterre & Negative \\
\hline $\begin{array}{l}\text { Faire baisser les coûts de construction: la } \\
\text { tentation du low cost }\end{array}$ & $12-03-22$ & Les Echos & Negative \\
\hline Des espaces devenus conviviaux & $12-04-04$ & $\begin{array}{l}\text { Les cahiers Techniques du } \\
\text { bâtiment }\end{array}$ & Positive \\
\hline $\begin{array}{c}\text { Il achète un hôtel } 4 \text { étoiles pour ... } 1000 \text { francs } \\
\text { suisses! }\end{array}$ & $12-07-19$ & La vie Immo (site web) & Neutral \\
\hline Les défis romands des CFF & $12-09-12$ & 24 heures & Negative \\
\hline Il faudrait enterrer les centres commerciaux & $12-10-01$ & Le Temps & Positive \\
\hline Le sous-sol, horizon neuf des villes & $12-10-01$ & Le Temps & Positive \\
\hline $\begin{array}{c}\text { Une coopérative zurichoise mène la révolution } \\
\text { de l'énergie }\end{array}$ & $12-11-18$ & Le Matin & Negative \\
\hline Getrennte Stadtteile wieder verbinden & 13-01-01 & TEC21 & Neutral \\
\hline Un plan B pour le Musée d'art et d'histoire & $13-02-08$ & Le Temps & Positive \\
\hline $\begin{array}{c}\text { Bagarre en vue autour de l'extension de } \\
\text { Cornavin }\end{array}$ & $13-04-06$ & $\begin{array}{l}\text { Contocollias-Tribune de } \\
\text { Genève }\end{array}$ & Neutral \\
\hline $\begin{array}{l}\text { L'initiative pour l'extension souterraine de } \\
\text { Cornavin est lancée }\end{array}$ & $13-04-10$ & Marc Moulin-Le Temps & Neutral \\
\hline Quand le rêve se confronte à la réalité & $13-08-08$ & L'Hebdo & Negative \\
\hline Apprenons à construire la ville souterraine & $13-08-23$ & Le Temps & Positive \\
\hline Dans le ventre de la Défense & $13-09-12$ & Les Echos & Negative \\
\hline Quel futur pour le musée d'art et d'histoire & $13-09-27$ & Tribune de Genève & Positive \\
\hline $\begin{array}{c}\text { Le musée d'art et d'histoire commence à se } \\
\text { dévoiler }\end{array}$ & $13-11-14$ & Tribune de Genève & Neutral \\
\hline Personne ne veut plus étendre la gare en surface & $13-11-21$ & Tribune de Genève & Neutral \\
\hline $\begin{array}{l}\text { Billiger bauen für die Ziele der } \\
\text { 2000-Watt-Gesellschaft }\end{array}$ & $13-12-06$ & Tages Anzeiger & Negative \\
\hline $\begin{array}{c}\text { Une galerie commerciale sera creusée sous la } \\
\text { tour Eiffel }\end{array}$ & $13-12-06$ & Newsnet/Tribune de Genève & Neutral \\
\hline Skylab, lieu de vies en zone industrielle & $14-03-05$ & Le Temps & Neutral \\
\hline Le quartier réinventé & $14-03-07$ & Tribune de Genève & Neutral \\
\hline Voyage sous terre & $14-03-28$ & L'Est Républicain & Neutral \\
\hline
\end{tabular}


Table A1. Cont.

\begin{tabular}{|c|c|c|c|}
\hline Article Title & Date & Source & Portrayal \\
\hline Quels garde-fous pour le site de Lavaux? & $14-05-02$ & La Liberté & Negative \\
\hline $\begin{array}{l}\text { Deux lois dessinent au mètre près l'avenir bâti } \\
\text { de Lavaux }\end{array}$ & $14-05-02$ & 24 heures & Neutral \\
\hline $\begin{array}{c}\text { Quelle place pour le stockage des voitures en } \\
\text { ville? }\end{array}$ & $14-05-13$ & $\begin{array}{l}\text { AMC le Moniteur } \\
\text { Architecture } n 233\end{array}$ & Neutral \\
\hline Toujours plus de vies souterraines & $14-07-26$ & La Liberté & Neutral \\
\hline Le nouveau MEG s'ouvre aux Genevois & $14-10-13$ & Tribune de Genève & Neutral \\
\hline $\begin{array}{c}\text { Marco Graber et Thomas Pulver réinventent } \\
\text { l'espace muséal }\end{array}$ & $14-10-25$ & Tribune de Genève & Neutral \\
\hline Spitze mit Tiefgang & $15-01-01$ & Hochparterre & Positive \\
\hline Suspendre un bâtiment souterrain & $15-01-30$ & Tracés & Positive \\
\hline L'Etat pourrait enterrer un projet de parking & $15-03-06$ & 24heures (Suisse) & Neutral \\
\hline La gare souterraine & $15-03-12$ & Tribune de Genève & Positive \\
\hline $\begin{array}{l}\text { Verzicht ist auch eine Form der } \\
\text { Reduktion-(Graue Energie) }\end{array}$ & $15-03-26$ & TEC21 & Negative \\
\hline Une ville sous la ville & $15-06-01$ & Migros Magazine & Neutral \\
\hline Un quartier écologique en dehors de la ville & $15-09-15$ & $\begin{array}{c}\text { Alain Détraz-24heures } \\
\text { (Suisse) }\end{array}$ & Neutral \\
\hline $\begin{array}{l}\text { Un parking recyclable conçu pour } \\
\text { l'après-voiture }\end{array}$ & $15-09-23$ & La Gazette des communes & Negative \\
\hline $\begin{array}{l}\text { Le futur métro du Grand Paris sera vertueux au } \\
\text { plan environnemental }\end{array}$ & $15-11-20$ & L'usine nouvelle & Positive \\
\hline Cornavin un succès né d'une union & $15-12-08$ & Tribune de Genève & Neutral \\
\hline La gare souterraine ne sera prête qu'en 2031 & $15-12-08$ & Tribune de Genève & Neutral \\
\hline $\begin{array}{c}\text { "J'ai compris que les grottes étaient } \\
\text { intouchables" }\end{array}$ & $15-12-09$ & Tribune de Genève & Positive \\
\hline $\begin{array}{c}\text { Le canton de la ville de Genève dégendent le } \\
\text { projet Nouvel }\end{array}$ & $16-01-26$ & Le Temps & Positive \\
\hline $\begin{array}{l}\text { Les idées fusent pour adapter les transports aux } \\
\text { exigences } d u \text { XXIe siècle }\end{array}$ & $16-01-31$ & Le Matin Dimanche & Neutral \\
\hline $\begin{array}{c}\text { Suisse: un projet de réseau souterrain pour les } \\
\text { marchandises. }\end{array}$ & $16-02-09$ & $\begin{array}{l}\text { Logistique Magazine } \\
\text { Newsletter }\end{array}$ & Positive \\
\hline Un musée et sa cour au cour des débats & $16-02-18$ & Le Temps & Positive \\
\hline $\begin{array}{l}\text { Les Genevois désavouent un projet de Jean } \\
\text { Nouvel }\end{array}$ & $16-03-01$ & Le Monde & Neutral \\
\hline $\begin{array}{c}\text { Musée d'art et d'histoire des leçons à tirer du } \\
\text { passé }\end{array}$ & $16-03-01$ & Tribune de Genève & Neutral \\
\hline Réinventer l'offre foncière & $16-03-08$ & Business immo & Positive \\
\hline Les gares du nouveau Grand Paris & $16-04-01$ & Le moniteur & Positive \\
\hline $\begin{array}{c}\text { Von «Undine» zum } \\
\text { Elsässerrheinweg-(Untergrund) }\end{array}$ & $16-05-12$ & TEC21 & Neutral \\
\hline Erdwärme ergänzt die Stromwende & $16-05-19$ & Handelszeitung & Positive \\
\hline Les élus doivent libérer 120 millions pour la gare & $16-05-26$ & Tribune de Genève & Neutral \\
\hline $\begin{array}{l}\text { La gare cornavin bridée dans ses futures } \\
\text { extensions }\end{array}$ & $16-06-13$ & Tribune de Genève & Neutral \\
\hline
\end{tabular}


Table A1. Cont.

\begin{tabular}{|c|c|c|c|}
\hline Article Title & Date & Source & Portrayal \\
\hline Dans les caves du Palais, à Genève & $16-08-18$ & D. Nikolic-Le Temps & Neutral \\
\hline $\begin{array}{l}\text { GE le parlement vote le crédit d'investissement } \\
\text { de } 42,528 \text { millions }\end{array}$ & $16-09-22$ & $S D A$ & Neutral \\
\hline 425 milions votés pour Cornavin & $16-09-23$ & Tribune de Genève & Neutral \\
\hline $\begin{array}{c}\text { L'extension de la gare Cornavin se livre à une } \\
\text { course contre le montre }\end{array}$ & $16-09-24$ & Tribune de Genève & Neutral \\
\hline $\begin{array}{l}\text { Le Musée d'art et d'histoire classé en bonne et } \\
\text { due forme }\end{array}$ & $16-10-11$ & Le Temps & Neutral \\
\hline Un parking au mauvais endroit & $16-10-18$ & La Liberté & Negative \\
\hline $\begin{array}{l}\text { L'entreprise gestionnaire du service public face } \\
\text { aux métamorphoses du stationnement }\end{array}$ & $16-10-27$ & Le moniteur & Neutral \\
\hline Die kluge Wahl der Mittel-(Untergrund) & $16-11-17$ & TEC21 & Negative \\
\hline $\begin{array}{l}\text { Der Untergrund ist der blinde Fleck der } \\
\text { Raumplaner }\end{array}$ & $16-11-26$ & Südostschweiz & Neutral \\
\hline Schwergewichtiger Rock $n$ Roll-(Untergrund) & $16-12-01$ & TEC21 & Positive \\
\hline $\begin{array}{c}\text { Le souterrain, avenir durable pour Homo } \\
\text { urbanus }\end{array}$ & $17-01-13$ & Journal de l'environnement & Positive \\
\hline Stationnement 600 places à trouver pour l'été & $17-01-31$ & Le télégramme & Negative \\
\hline $\begin{array}{l}\text { "Resources to needs": a paradigm for } \\
\text { addressing the potentiality of the urban volume }\end{array}$ & $17-03-01$ & Urban Planning & Positive \\
\hline $\begin{array}{l}\text { Le projet de parking souterrain d'Yverdon } \\
\text { remonte à la surface }\end{array}$ & $17-03-10$ & F.RA.-24heures (Suisse) & Neutral \\
\hline $\begin{array}{c}\text { L'urbanisme souterrain est-il l'avenir du } \\
\text { vertical? }\end{array}$ & $17-04-24$ & $\begin{array}{l}\text { La gazette des communes } \\
\text { (site web }\end{array}$ & Neutral \\
\hline l'extension du métro bruxellois & $17-05-19$ & Le vif & Positive \\
\hline Après l'aérien, le souterrain low cost. & $17-06-01$ & Luc Debraine-Le Temps & Neutral \\
\hline $\begin{array}{c}\text { Réinventer Paris: le Relais d'Italie officiellement } \\
\text { engagé }\end{array}$ & $17-06-09$ & Business Immo (site web) & Neutral \\
\hline $\begin{array}{c}\text { Le MAH de Genève va se transformer en } \\
\text { campus muséal }\end{array}$ & $17-06-29$ & $S D A$ & Neutral \\
\hline $\begin{array}{c}\text { Les Veveysans ont pu rêver la place du marché } \\
\text { idéale }\end{array}$ & $17-07-04$ & 24 Heures & Negative \\
\hline Bauzone, Bauern, Untergrund & 17-09-01 & Hochparterre & Neutral \\
\hline $\begin{array}{c}\text { Les CFF envisagent une gare souterraine à } \\
\text { Lausanne en 2050-2060 }\end{array}$ & $17-10-03$ & RTS.ch & Positive \\
\hline $\begin{array}{l}\text { Tunnels-Congrès Aftes 2017: pourquoi l'espace } \\
\text { souterrain est devenu un enjeu de premier plan? }\end{array}$ & $17-10-09$ & $\begin{array}{c}\text { Chantiers de France (site } \\
\text { web) }\end{array}$ & Positive \\
\hline
\end{tabular}

\section{References}

1. Jorio, L. Eight Things You Should Know about the Gotthard. In Swissinfo.ch; Swiss Broadcasting Corporation: Bern, Switzerland, 2016.

2. Pia, F. Urbaniser les Alpes suisses. Stratégies de densification des villes en altitude. Ph.D. Thesis, École polytechnique fédérale de Lausanne, Lausanne, Switzerland, 2016.

3. Parriaux, A.; Blunier, P.; Maire, P.; Dekkil, G.; Tacher, L. Projet Deep City: Ressources du Sous-sol et Développement Durable des Espaces Urbains; vdf Hochschulverlag AG an der ETH Zürich: Lausanne, Switzerland, 2010; ISBN 978-3-7281-3332-8. 
4. Office fédéral du développement territorial (ARE). Révision de la loi sur l'aménagement du territoire (LAT); Office fédéral du développement territorial: Bern, Switzerland, 2018.

5. Maire, P. Étude multidisciplinaire d'un développement durable du sous-sol urbain. Aspects socio-économiques, juridiques et de politique urbaine. Ph.D. Thesis, Swiss Federal Institute of Technology Lausanne (EPFL), Lausanne, Switzerland, 2011.

6. Golany, G.; Ojima, T. Geo-Space Urban Design; John Wiley: New York, NY, USA, 1996; ISBN 0-471-16252-3.

7. Nishi, J.; Tanaka, T.; Seiki, T.; Ito, H.; Okuyama, K. Estimation of the value of the internal and external environment in underground space use. Tunn. Undergr. Space Technol. 2000, 15, 79-89. [CrossRef]

8. Suisse Énergie. L'énergie grise dans les nouveaux bâtiments: Guide pour les professionels du bâtiment; Office fédérale de l'Énergie (OFEN): Ittigen, Switzerland, 2017.

9. Poux, A. Construire en souterrain: Une solution avantageuse pour l'environnement? Master's Thesis, École Centrale Nantes and École polytechnique fédérale de Lausanne, Lausanne, Switzerland, 2008.

10. Labs, K. The Architectural Use of Underground Space, Issues and Applications. Master's Thesis, Washington Universty in Saint Louis, St. Louis, MO, USA, 1975.

11. Barker, M.B. Using the earth to save energy: Four underground buildings. Tunn. Undergr. Space Technol. 1986, 1, 59-65. [CrossRef]

12. Carmody, J.; Sterling, R.L. Underground Space Design: A Guide to Subsurface Utilization and Design for People in Underground Spaces; Van Nostrand Reinhold: New York, NY, USA, 1993; ISBN 0-442-01383-3.

13. Alkaff, S.A.; Sim, S.C.; Ervina Efzan, M.N. A review of underground building towards thermal energy efficiency and sustainable development. Renew. Sustain. Energy Rev. 2016, 60, 692-713. [CrossRef]

14. Kaliampakos, D.; Benardos, A.; Mavrikos, A. A review on the economics of underground space utilization. Tunn. Undergr. Space Technol. 2016, 55, 236-244. [CrossRef]

15. Winsberg, E.B. Computer Simulations in Science. In The Stanford Encyclopedia of Philosophy; Zalta, E.N., Ed.; The Metaphysics Research Lab, Center for the Study of Language and Information, Stanford University: Stanford, CA, USA, 2018.

16. Winsberg, E.B. Science in the Age of Computer Simulation; The University of Chicago Press: Chicago, CA, USA, 2010; ISBN 978-0-226-90202-9.

17. International Standards Organization (ISO). ISO 14040:2006. Environmental Management_Life Cycle Assessment; International Standards Organization (ISO): Geneva, Switzerland, 2006.

18. Minergie Switzerland Minergie Standard. Available online: https://www.minergie.ch/fr/ (accessed on 14 August 2019).

19. KBOB. Données des écobilans dans la construction; KBOB, Office fédéral des constructions et de la logistique: Bern, Switzerland, 2017.

20. Citherlet, S. Towards the Holistic Assessment of Building Performance Based on an Integrated Simulation Approach. Ph.D. Thesis, École polytechnique fédérale de Lausanne, Lausanne, Switzerland, 2001.

21. MIKE, powered by DHI. FEFLOW. Hørsholm, Denmark. Available online: https://www.mikepoweredbydhi. com/products/feflow (accessed on 14 August 2019).

22. Samard, F. Pour se densifier, les villes vont aussi se développer en sous-sol. Le Progrès, 26 October 2011; 13.

23. Petro, L. Billiger bauen für die Ziele der 2000-Watt-Gesellschaft. Tages Anzeiger, 6 December 2013.

24. Imstepf, É.W. Un quartier mixte revalorise Neuchâtel. La Liberté, 10 April 2007; 35.

25. Le Bé, P. Ecoquartiers: Quand le rêve se confronte à la réalité. L'Hebdo, 8 August 2013; 34.

(C) 2019 by the authors. Licensee MDPI, Basel, Switzerland. This article is an open access article distributed under the terms and conditions of the Creative Commons Attribution (CC BY) license (http://creativecommons.org/licenses/by/4.0/). 